\title{
Kesulitan Siswa Kelas X MIA SMA Negeri di Kota Palangka Raya Tahun Ajaran 2018/2019 dalam Memahami Konsep Ikatan Kimia dengan Menggunakan Instrumen Two-Tier Multiple Choice
}

\author{
The Difficulties of X Grade High School Students in Palangka Raya \\ City Academic Year of 2018/2019 in Understanding Chemical Bond \\ Concept using Two-Tier Multiple Choice
}

\author{
Novieta Sari ${ }^{1 *}$, Suandi Sidauruk ${ }^{2}$, Ruli Meiliawati ${ }^{3}$, Anggi Ristiyana \\ Puspita Sari $^{4}$
}

Jurusan Pendidikan MIPA/FKIP - Universitas Palangka Raya,

Palangka Raya Indonesia - 73111

Email: novietasari007@gmail.com

\begin{abstract}
Abstrak
Konsep ikatan kimia merupakan salah satu konsep yang kurang dikuasai oleh siswa, sehingga perlu adanya tes diagnostik untuk menentukan kesulitan yang dialami siswa. Penelitian ini bertujuan untuk mendeskripsikan kesulitan siswa dalam memahami konsep ikatan kimia dengan menggunakan instrumen two-tier multiple choice yang meliputi subkonsep: (1) konfigurasi elektron stabil, (2) elektron valensi, (3) ikatan ion, (4) ikatan kovalen, dan (5) ikatan logam. Subjek penelitian ini adalah siswa kelas X MIA dari SMA Negeri 1 Palangka Raya, SMA Negeri 3 Palangka Raya, dan SMA Negeri 4 Palangka Raya dengan jumlah total subjek penelitian adalah 335 siswa. Kesulitan siswa dalam memahami konsep ikatan kimia diungkapkan dengan menggunakan Tes Kemampuan Ikatan Kimia (TKIK) dalam bentuk soal pilihan ganda beralasan (two-tier multiple choice) sebanyak 15 soal dan wawancara untuk mengkonfirmasi kesulitan yang dialami siswa. Hasil uji coba terhadap TKIK menunjukkan reliabilitas 0,68 ; daya beda 0,5 ; dan tingkat kesukaran 0,41 . Hasil penelitian menunjukkan bahwa kesulitan siswa dalam memahami konsep ikatan kimia dengan persentase kesulitan paling sulit hingga mudah secara berurutan yaitu menentukan ikatan kovalen sebesar 58,7\%; menentukan ikatan ion sebesar $55,4 \%$; menentukan ikatan logam sebesar 54,3\%; menentukan konfigurasi elektron stabil sebesar 35,8\%; dan menentukan elektron valensi sebesar $35,1 \%$.
\end{abstract}

Kata Kunci: ikatan kimia, kesulitan, pemahaman konsep, two-tier multiple choice

\begin{abstract}
The concept of chemical bonds is one of the concepts that students are less familiar with, so there is a need for a diagnostic test to determine students' difficulty. This study aims to describe students' difficulties in
\end{abstract}


understanding the concept of chemical bonds using two-tier multiplechoice which includes the following sub: (1) stable electron configuration, (2) valence electrons, (3) ionic bonds, (4) covalent bonds, and (5) metal bonds. The subjects of this study were students of class X MIA from SMA Negeri 1 Palangka Raya, SMA Negeri 3 Palangka Raya, and SMA Negeri 4 Palangka Raya with a total number of research subjects being 335 students. Students' difficulties in understanding the concept of chemical bonds were expressed using the Tes Kemampuan Ikatan Kimia (TKIK) form two-tier multiple choice of 15 questions and interviews to confirm the students' difficulty. The test results of TKIK showed a reliability of 0.68 , an item discrimination power of 0.5 , and an item difficulty level of 0.41 . The results showed that the difficulty of the students in understanding the concept of chemical bonds with the percentage of the most difficult to easy difficulties was in order to determine the covalent bonds of $58.7 \%$, determined the ionic bond at $55.4 \%$, determined the metal bond at $54.3 \%$, determined the stable electron configuration of $35.8 \%$, and determine the valence electrons at $35.1 \%$.

Keywords: chemical bonds, concept understanding, difficulty, two-tier multiple choice

\section{PENDAHULUAN}

Kimia merupakan salah satu cabang ilmu dari Ilmu Pengetahuan Alam (IPA) yang lebih memerlukan pemahaman konsep daripada hafalan. Hal tersebut dikarenakan kimia merupakan ilmu yang banyak memiliki konsep yang abstrak. Banyaknya konsep yang abstrak membuat ilmu kimia menjadi kurang diminati oleh siswa. Selain itu, bahasa yang digunakan dalam pemecahan masalah dan perhitungan seringkali membuat siswa mengalami kesulitan. Siswa cenderung kesulitan dalam memahami informasi yang diperoleh dari soal, seperti menuliskan lambang, rumusrumus, hingga menyelesaikan soal yang memerlukan keahlian operasi matematika (Arifin, 2007). Kesulitan siswa dalam mempelajari dan memahami suatu materi ini sudah menjadi perhatian bagi para peneliti di bidang pendidikan selama bertahun-tahun (Pérez, et al., 2017).

Tercapai atau tidaknya tujuan pembelajaran yang diinginkan, perlu dilakukan evaluasi untuk mengetahui kesulitan siswa dalam pembelajaran tersebut. Seorang guru patut dibekali dengan evaluasi sebagai yang mendukung tugasnya yakni mengevaluasi hasil belajar siswa. Guru bertugas mengukur apakah siswa sudah menguasai ilmu yang dipelajari oleh siswa atas bimbingan guru sesuai dengan tujuan yang dirumuskan. Apabila diketahui terdapat siswa yang mengalami kesulitan dalam mempelajari suatu topik tertentu, maka guru perlu mengintropeksi cara mengajar, mencari sebab-sebab siswa mengalami kesulitan dalam belajar, 
dan selanjutnya mengupayakan perbaikan atau penyesuaian cara mengajar dengan jenis materi yang diajarkan (Arikunto, 2007). Upaya tersebut dapat meningkatkan motivasi belajar siswa, sehingga siswa menjadi tertarik untuk mempelajari materi bahkan yang cenderung dianggap sulit sekalipun.

Salah satu pokok bahasan yang terdapat pada mata pelajaran kimia SMA Kelas X MIA adalah ikatan kimia. Hasil pengamatan peneliti pada saat melakukan PPL II di SMA Negeri Palangka Raya diketahui bahwa dalam mempelajari materi ikatan kimia, kesulitan yang dialami oleh sebagian siswa adalah menentukan struktur Lewis, rumus kimia senyawa, dan jenis ikatan yang terjadi pada suatu senyawa. Bebrapa penelitian yang telah dilakukan oleh Destama (2016), Qomariah (2016), dan Herdiyansah (2017) juga membuktikan bahwa materi ikatan kimia merupakan materi yang sulit untuk dipahami siswa. Hasil dari penelitian tersebut menyatakan bahwa siswa mengalami kesulitan pada subkonsep konfigurasi elektron, menentukan jumlah elektron valensi, menggambarkan struktur Lewis, menuliskan rumus molekul, menentukan kecenderungan suatu unsur mencapai kestabilan, menentukan atom mengikuti aturan oktet/duplet, meramalkan rumus senyawa yang terbentuk, dan meramalkan jenis ikatan berdasarkan struktur Lewis.

Salah satu cara untuk dapat mengetahui kesulitan siswa dalam memahami suatu konsep adalah menggunakan tes diagnostik yakni soal pilihan ganda dua tingkat (two-tier multiple choice). Tes ini terdiri atas dua tingkat, tingkat pertama merupakan pertanyaan mengenai konsep yang diujikan dan tingkat kedua merupakan alasan dari jawaban pada tingkat pertama. Instrumen two-tier multiple choice ini merupakan instrumen yang efektif untuk dapat mengidentifikasi tingkat pemahaman konsep dan telah digunakan oleh beberapa peneliti. Keunggulan dari instrumen ini adalah proses penyusunan dan analisisnya yang mudah (Mutlu \& Sesen, 2014; Widiyatmoko \& Shimizu, 2018). Oleh karena itu, guru dapat mengidentifikasi siswa yang mengalami miskonsepsi dan tidak paham konsep terhadap materi yang telah diajarkan.

Bagaimanapun juga, instrumen yang memiliki beberapa keunggulan tersebut masih jarang digunakan oleh guru kimia SMA di Kota Palangka Raya. Berdasarkan latar belakang masalah tersebut, maka pengembangan instrumen two-tier multiple choice perlu dilakukan untuk mengidentifikasi kesulitan yang dialami siswa dalam memahami konsep ikatan kimia. 


\section{BAHAN DAN METODE}

Jenis penelitian ini adalah penelitian deskriptif. Penelitian deskriptif adalah suatu bentuk penelitian yang ditujukan untuk mendeskripsikan fenomena-fenomena yang ada, baik fenomena alamiah maupun fenomena buatan manusia. Fenomena ini biasa berupa bentuk, aktivitas, karakteristik, perubahan, hubungan, kesamaan, dan perbedaan antara fenomena lainnya (Sukmadinata, 2008). Sementara itu, pendekatan yang dilakukan pada penelitian ini beupa pendekatan kuantitatif, yakni pendekatan yang dibangun berdasarkan teori atau penelitian sebelumnya. Variabel-variabel yang dalam pertanyaan penelitian atau hipotesis tersebut selanjutnya diukur dengan instrumen penelitian yang telah ditentukan sebelumnya. Penelitian ini berusaha mendeskripsikan kesulitan siswa kelas X MIA SMA di Kota Palangka Raya Tahun Ajaran 2018/2019 dalam memahami konsep ikatan kimia dengan menggunakan instrumen two-tier multiple choice.

Instrumen yang digunakan berupa two-tier multiple choice yang terdiri atas 15 butir soal. Data penelitian berupa hasil tes kemampuan siswa dalam mengerjakan butir soal dalam two-tier multiple choice. Tahap-tahap yang dilakukan dalam penelitian ini meliputi: 1) pemberian soal TKIK kepada siswa, 2) pengelopmpokkan jawaban siswa sesuai kriteria jawaban benar, dan 3) hasil pengelompokkan jawaban siswa digunakan untuk menentukan dominasi jawaban yang dipilih siswa, sehingga ditemukan siswa yang mengalami kesulitan, 4) wawancara perwakilan siswa yang mengalami kesulitan.

\section{HASIL}

Data hasil jawaban dikelompokkan berdasarkan kriteria tingkat pemahaman yang terdapat pada tabel klasifikasi jawaban siswa yakni Tabel 1 (Sidauruk, 2005).

Tabel 1. Klasifikasi Jawaban Siswa

\begin{tabular}{lcc}
\hline $\begin{array}{c}\text { Pola Jawaban } \\
\text { Siswa }\end{array}$ & Kode & $\begin{array}{c}\text { Kategori } \\
\text { Pemahaman }\end{array}$ \\
\hline $\begin{array}{l}\text { Jawaban inti } \\
\text { tes benar- }\end{array}$ & BB & Paham Konsep \\
alasan benar & & \\
\hline $\begin{array}{l}\text { Jawaban inti } \\
\text { tes benar- } \\
\text { alasan salah }\end{array}$ & BS & \\
\hline
\end{tabular}




\begin{tabular}{llc}
$\begin{array}{l}\text { Jawaban inti } \\
\text { tes salah- } \\
\text { alasan benar }\end{array}$ & SB & Miskonsepsi \\
\cline { 1 - 2 } $\begin{array}{l}\text { Jawaban inti } \\
\text { tes salah- } \\
\text { alasan salah }\end{array}$ & SS & \\
\hline $\begin{array}{l}\text { Tidak } \\
\text { Menjawab }\end{array}$ & TM & $\begin{array}{c}\text { Tidak Paham } \\
\text { Konsep }\end{array}$ \\
\hline
\end{tabular}

Pada Tabel 1 siswa yang termasuk dalam paham konsep merupakan siswa yang tidak mengalami kesulitan dalam menyelesaikan tes kemampuan ikatan kimia, sedangkan siswa yang termasuk dalam miskonsepsi dan tidak paham konsep merupakan siswa yang dianggap mengalami kesulitan dalam menyelesaikan tes kemampuan ikatan kimia. Persentase siswa paham konsep dan siswa yang mengalami kesulitan pada setiap butir soal disajikan dalam Tabel 2.

Tabel 2. Persentase Kesulitan Siswa pada Setiap Butir Soal

\begin{tabular}{ccccc}
\hline \multirow{2}{*}{$\begin{array}{c}\text { No } \\
\text { Soal }\end{array}$} & \multirow{4}{*}{ PK } & \multicolumn{3}{c}{ Kategori Jawaban (\%) } \\
\cline { 2 - 5 } & & M & TP & TK \\
\hline 1 & 60,0 & 35,8 & 4,2 & 40,0 \\
\hline 2 & 68,7 & 26,3 & 5,0 & 31,3 \\
\hline 3 & 77,9 & 18,8 & 3,3 & 22,1 \\
\hline 4 & 71,0 & 25,7 & 3,3 & 29,0 \\
\hline 5 & 46,0 & 46,9 & 7,1 & 54,0 \\
\hline 6 & 40,6 & 52,2 & 7,2 & 59,4 \\
\hline 7 & 64,5 & 29,3 & 6,2 & 35,5 \\
\hline 8 & 34,9 & 57,9 & 7,2 & 65,1 \\
\hline 9 & 38,8 & 52,8 & 8,4 & 61,2 \\
\hline 10 & 42,1 & 49,0 & 8,9 & 57,9 \\
\hline 11 & 41,5 & 49,0 & 9,5 & 58,5 \\
\hline 12 & 40,6 & 51,0 & 8,4 & 59,4 \\
\hline 13 & 40,3 & 48,7 & 11,0 & 59,7 \\
\hline 14 & 48,1 & 40,6 & 11,3 & 51,9 \\
\hline 15 & 48,7 & 44,5 & 6,8 & 51,3 \\
\hline
\end{tabular}

Keterangan:

$\mathrm{PK}=$ Paham Konsep

$\mathrm{M}=$ Miskonsepsi

$\mathrm{TP}=$ Tidak Paham

TK = Total Kesulitan

Berdasarkan data pada Tabel 2 persentase kesulitan siswa paling tinggi terdapat pada butir soal 8 tentang ikatan ion yaitu sebesar $65,1 \%$, sedangkan persentase kesulitan siswa paling rendah yaitu pada butir soal 3 tentang sebesar $22,1 \%$. Sementara itu, persentase kesulitan siswa dalam 
menyelesaikan tes kemampuan ikatan kimia pada setiap subkonsep disajikan pada Tabel 3.

Tabel 3. Persentase Kesulitan Siswa pada Setiap Subkonsep

\begin{tabular}{lcccc}
\hline \multirow{2}{*}{ Subkonsep } & \multirow{4}{c}{ Kategori Jawaban (\%) } \\
\cline { 2 - 5 } & PK & M & TP & TK \\
\cline { 2 - 5 } & & 31,1 & 4,6 & 35,7 \\
\hline $\begin{array}{l}\text { Konfigurasi elektron } \\
\text { stabil }\end{array}$ & 64,3 & 30,5 & 4,6 & 35,1 \\
\hline Elektron valensi & 64,9 & 48,0 & 7,3 & 55,3 \\
\hline Ikatan ion & 44,7 & 49,6 & 9,0 & 58,6 \\
\hline Ikatan kovalen & 41,4 & 44,6 & 9,7 & 54,3 \\
\hline Ikatan logam & 45,7 & & 239 \\
\hline Jumlah & 261 & \multicolumn{4}{c}{47,8} \\
\hline Rata-rata & 52,2 & &
\end{tabular}

Keterangan:

PK = Paham Konsep

$\mathrm{M}=$ Miskonsepsi

$\mathrm{TP}=$ Tidak Paham

TK = Total Kesulitan

Berdasarkan data pada Tabel 3 persentase kesulitan siswa paling tinggi terdapat pada subkonsep ikatan kovalen sebesar 58,6\%, sedangkan persentase kesulitan siswa paling rendah yaitu pada subkonsep elektron valensi sebesar $35,1 \%$. Persentase rata-rata kesulitan yang dialami siswa dalam memahami konsep ikatan kimia sebesar 47,8\%. Hal tersebut menandakan masih banyak siswa yang mengalami kesulitan dalam memahami konsep ikatan kimia yang disebabkan karena miskonsepsi yang dialami siswa dan tidak paham konsep pada materi ikatan kimia.

Sementara itu, kesulitan siswa paling dominan dalam menyelesaikan tes kemampuan ikatan kimia terdapat pada subkonsep keempat yakni subkonsep ikatan kovalen. Oleh karena itu, disajikan rincian data pada butir soal nomor 12 yang merupakan subkonsep ikatan kovalen. Distribusi jawaban-alasan siswa pada butir soal nomor 12 tersebut disajikan pada Tabel 4.

Pada butir soal nomor 12 disajikan gambar struktur Lewis dari senyawa $\mathrm{HClO}_{4}$, siswa diminta untuk menentukan ikatan terdapat pada gambar. Jawaban benar dari ikatan yang ditunjukkan oleh nomor 1 dan 5 pada gambar soal adalah ikatan kovalen koordinasi (opsi D) dengan alasan karena elektron yang digunakan bersama berasal dari unsur $\mathrm{Cl}$ (opsi 5). 
Tabel 4. Distribusi Pasangan Jawaban-Alasan Siswa pada Butir Soal 12 Subkonsep Ikatan Kovalen

\begin{tabular}{ccccccc}
\hline \multicolumn{7}{c}{ Pola Jawaban Siswa } \\
\hline Opsi & 1 & 2 & 3 & 4 & 5 & TM \\
\cline { 2 - 8 } Jawaban & 3 & 3 & & & 7 & \\
\hline A & 7 & 9 & 4 & 3 & 15 & \\
\hline B & 20 & 10 & 14 & 6 & 32 & \\
\hline C & 11 & 9 & 8 & 10 & 134 & \\
\hline D & & & & & 3 & \\
\hline E & & & & & 28 \\
\hline TM
\end{tabular}

Siswa yang menjawab benar pada butir soal nomor 12 sebanyak 134 siswa, artinya 201 siswa menjawab salah. Jawaban salah dominan pada butir soal nomor 12 yakni siswa menjawab ikatan yang ditunjukkan oleh nomor 1 dan 5 pada gambar soal adalah ikatan kovalen rangkap dua (opsi C) dengan alasan karena elektron yang digunakan bersama berasal dari unsur $\mathrm{Cl}$ (opsi 5). Jawaban salah siswa tersebut disajikan pada Gambar 1.

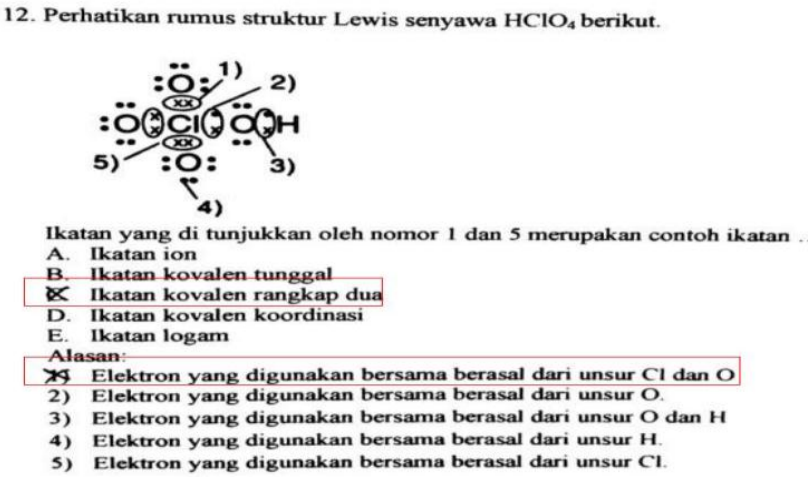

Gambar 1. Jawaban Salah Dominan Soal

Nomor 12 pada Subkonsep Ikatan Kovalen

Jawaban salah siswa yang ditunjukkan pada Gambar 1 tersebut disebabkan karena siswa beranggapan bahwa ikatan yang ditunjukkan oleh nomor 1 dan 5 pada soal merupakan ikatan kovalen rangkap dua, karena terdapat dua elektron yang digunakan unsur $\mathrm{O}$ untuk berikatan dengan unsur $\mathrm{Cl}$. Sepasang elektron yang digunakan untuk berikatan merupakan elektron yang berasal hanya dari atom $\mathrm{Cl}$ atau salah satu atomnya, sehingga berdasarkan hal tersebut siswa tidak paham mengenai ikatan yang terbentuk bukan merupakan ikatan kovalen rangkap dua, melainkan ikatan koordinasi. Berikut adalah kutipan wawancara yang dilakukan untuk memperjelas jawaban siswa dalam menyelesaikan butir soal 12 . 
Cuplikan wawancara 1:

$P$ : Selamat siang dek. $S$ : Selamat siang bu.

$P$ : Perhatikan soal nomor 12, apa alasan kamu memilih pilihan $C$ dan pilihan alasan 5?

$S$ :Karena atom $\mathrm{O}$ mengikat dua elektron dari $\mathrm{Cl}$ bu, jadi saya menyimpulkan kalau ikatannya ikatan kovalen rangkap dua.

$P$ : Apa yang dimaksud dengan ikatan kovalen rangkap dua?

$S$ :Ikatan yang terjadi karena penggunaan dua pasang elektron secara bersama-sama oleh atom penyusunnya.

$P$ : Berasal dari atom manakah elektron yang digunakan untuk berikatan pada gambar tersebut?

$S: C l b u$.

$P$ : Oke, jika menurutmu dua pasang elektron yang digunakan untuk berikatan berasal dari atom Cl. Apakah pada ikatan tersebut masih terjadi penggunaan elektron secara bersama-sama oleh atom penyusunnya?

S : Iya bu, masih. Karena pada ikatan tersebut terdapat dua elektron yang digunakan bersama-sama.

$P$ : Berarti menurut kamu meskipun atomnya hanya berasal dari atom $\mathrm{Cl}$, ikatannya tetap ikatan kovalen rangkap dua?

$S$ : Iya bu, karena elektron yang digunakan berikatan dua elektron. Jadi ikatannya ikatan kovalen rangkap dua.

$P$ : Apakah kamu yakin dengan jawabanmu?

$S$ : Yakin bu, karena saya masih ingat dari pelajaran semester 1 kemarin kalau ikatannya terjadi karena mengikat dua elektron berarti ikatan kovalen rangkap dua bu.

Persentase kesulitan siswa paling rendah terdapat subkonsep kedua yakni subkonsep elektron valensi. Kesulitan siswa dalam menentukan susunan elektron valensi suatu senyawa ditelusuri dengan menggunakan instrumen TKIK yang terdiri dari tiga butir soal, yakni butir soal nomor 3, 4, dan 5. Berdasarkan hasil tes yang telah dilakukan diperoleh rerata jumlah siswa yang mengalami kesulitan pada subkonsep elektron valensi sebesar $35,1 \%$, dengan persentase kesulitan pada butir soal nomor 3 sebesar $22,1 \%$, butir soal nomor 4 sebesar $29 \%$, dan butir soal nomor 5 sebesar 54\%, sehingga butir soal nomor 5 dengan kesulitan dominan pada 
subkonsep elektron valensi dideskripsikan untuk mengungkap kesulitan siswa dalam menyelesaikan TKIK dengan kategori jawaban salah-alasan salah, jawaban benar-alasan salah, jawaban salahalasan benar, dan tidak menjawab. Distribusi jawaban-alasan siswa pada butir soal nomor 5 tersebut disajikan pada tabel 5 berikut.

Tabel 5. Distribusi Pasangan Jawaban-Alasan Siswa pada Butir Soal 5 Subkonsep Elektron Valensi

\begin{tabular}{ccccccc}
\hline \multicolumn{7}{c}{ Pola Jawaban Siswa } \\
\hline Opsi & \multicolumn{7}{c}{ Alasan } \\
Jawaban & 1 & 2 & 3 & 4 & 5 & TM \\
\hline A & 76 & 2 & 9 & 2 & & \\
\hline B & 8 & 9 & 156 & 2 & 2 & \\
\hline C & 1 & 3 & 2 & 7 & & \\
\hline D & & 18 & 2 & 7 & & \\
\hline E & \multicolumn{7}{c}{2} & 1 & & 8 & \\
\hline TM & \multicolumn{7}{c}{} & & & & 24 \\
\hline
\end{tabular}

Pada butir soal nomor 5 disajikan konfigurasi elektron dari suatu unsur berdasarkan aturan Aufbau, siswa diminta untuk menentukan elektron valensi dari unsur tersebut. Jawaban benar elektron valensi dari unsur ${ }_{31} \mathrm{X}$ dengan konfigurasi elektron $1 \mathrm{~s}^{2} 2 \mathrm{~s}^{2} 2 \mathrm{p}^{6} 3 \mathrm{~s}^{2} 3 \mathrm{p}^{6} 4 \mathrm{~s}^{2} 3 \mathrm{~d}^{10} 4 \mathrm{p}^{1}$ adalah 3 (opsi B), dengan alasan karena jumlah elektron pada subkulit $4 \mathrm{~s}^{2}$ $+4 p^{1}$ (opsi 3). Siswa yang menjawab benar pada butir soal nomor 5 adalah sebanyak 156 siswa, artinya terdapat 179 siswa menjawab pilihan jawabanalasan salah. Jawaban salah dominan pada butir soal nomor 5 yakni siswa menjawab elektron valensi dari unsur ${ }_{31} \mathrm{X}$ dengan konfigurasi elektron $1 s^{2} 2 s^{2} 2 p^{6} 3 s^{2} 3 p^{6} 4 s^{2} 3 d^{10} 4 p^{1}$ adalah 1 (opsi A) dengan alasan karena jumlah elektron pada subkulit $4 p^{1}$ (opsi 1). Jawaban salah siswa tersebut disajikan pada Gambar 2.

Jawaban salah siswa pada butir soal nomor 5 yang ditunjukkan oleh Gambar 2 disebabkan karena siswa beranggapan bahwa elektron valensi dari unsur ${ }_{31} \mathrm{X}$ dengan konfigurasi elektron menurut Aufbau yakni $1 \mathrm{~s}^{2} 2 \mathrm{~s}^{2}$ $2 p^{6} 3 s^{2} 3 p^{6} 4 s^{2} 3 d^{10} 4 p^{1}$ ditentukan berdasarkan jumlah elektron pada kulit terluar unsur tersebut. Unsur ${ }_{31} \mathrm{X}$ mempunyai konfigurasi elektron yang berakhir pada kulit ke empat dan subkulit $\mathrm{p}$ yakni $4 \mathrm{p}^{1}$, hal tersebut menyebabkan siswa beranggapan bahwa unsur ${ }_{31} \mathrm{X}$ mempunyai elektron valensi yaitu 1. Berikut adalah kutipan wawancara yang dilakukan untuk memperjelas jawaban siswa dalam menyelesaikan butir soal nomor 5 . 
5. Diberikan unsur ${ }_{31} X$ mempunyai konfigurasi elektron yaitu $1 s^{2} 2 s^{2} 2 p^{6} 3 s^{2} 3 p^{6} 4 s^{2} 3 d^{10} 4$ Tentukan elektron valensi unsur tersebut ....
D. 11
E. 12
Alasan:
X Karena jumlah elektron pada subkulit $4 \mathrm{p}^{1}$.
2) Karena jumlah elektron pada subkulit $3 d^{10}+4 p^{1}$.
3) Karena jumlah elektron pada subkulit $4 s^{2}+4 p^{1}$.
4) Karena jumlah elektron pada subkulit $3 d^{10}$.
5) Karena jumlah elektron pada subkulit $3 d^{10}+4 s^{2}$.

Gambar 2. Jawaban Salah Dominan Soal Nomor 5 pada Subkonsep

\section{Elektron Valensi}

Jawaban salah siswa pada butir soal nomor 5 yang ditunjukkan oleh Gambar 2 disebabkan karena siswa beranggapan bahwa elektron valensi dari unsur ${ }_{31} \mathrm{X}$ dengan konfigurasi elektron menurut Aufbau yakni $1 \mathrm{~s}^{2} 2 \mathrm{~s}^{2}$ $2 p^{6} 3 s^{2} 3 p^{6} 4 s^{2} 3 d^{10} 4 p^{1}$ ditentukan berdasarkan jumlah elektron pada kulit terluar unsur tersebut. Unsur ${ }_{31} \mathrm{X}$ mempunyai konfigurasi elektron yang berakhir pada kulit ke empat dan subkulit $\mathrm{p}$ yakni $4 \mathrm{p}^{1}$, hal tersebut menyebabkan siswa beranggapan bahwa unsur ${ }_{31} \mathrm{X}$ mempunyai elektron valensi yaitu 1. Berikut adalah kutipan wawancara yang dilakukan untuk memperjelas jawaban siswa dalam menyelesaikan butir soal nomor 5 .

Cuplikan wawancara 2:

$P$ : Selamat siang dek.

$S$ : Siang bu.

$P$ : Coba perhatikan soal nomor 5, kenapa kamu memilih A dan alasannya 1 ?

$S$ : Karena saya meliat dikulit terakhirnya bu, kulit terakhirnya $4 p^{1}$ jadi elektronnya itu 1. Kemudian saya lihat lagi dari pilihan alasannya, alasan nomor 1 yang paling tepat untuk alasan dari jawabannya bu.

$P$ : Kalau misalkan konfigurasinya berakhir dikulit s, cara menentukan elektron valensi unsurnya seperti apa?

$S$ : Elektron dari kulit s itu juga bu yang menjadi elektron valensinya.

$P$ : Kalau berakhirnya di d bagaimana?

$S$ : Nah, kalau berakhirnya di d baru ditambahkan dengan s bu. Jadi elektron dikulit s ditambah dengan elektron dikulit d jumlahnya itu elektron valensinya bu. 
$P$ : Kaти yakin seperti itu? Dari penjelasan gurumu ketika mengajar seperti apa?

$S$ : Yang saya ingat memang seperti itu bu

Cuplikan wawancara 2 menunjukkan kesulitan yang dialami siswa dalam menentukan elektron valensi dari suatu unsur. Jawaban yang dipilih siswa yakni elektron valensi ditentukan oleh elektron yang terdapat pada subkulit terluar unsur tersebut, padahal kenyataannya dalam menentukan elektron valensi suatu unsur jika kulit terluarnya pada subkulit $\mathrm{p}$ dan $\mathrm{d}$ maka akan ditambahkan dengan elektron pada subkulit s, kecuali kulit terluarnya adalah s maka elektron valensinya yakni elektron yang terdapat pada subkulit tersebut. Miskonsepsi dan tidak paham konsep yang dialami siswa terhadap subkonsep elektron valensi menyebabkan siswa mengalami kesulitan dalam menentukan elektron valensi suatu unsur.

\section{PEMBAHASAN}

Penelitian ini bertujuan untuk mendeskripsikan kesulitan siswa dalam memahami konsep ikatan kimia dengan menggunakan instrumen two-tier multiple choice. Tes Kemampuan Ikatan Kimia (TKIK) merupakan tes tertulis berbentuk pilihan ganda dengan alasan, dimana pada setiap butir soal dalam tes ini memiliki dua bagian yaitu: 1) pernyataan soal dan pilihan jawaban, dan 2) pilihan alasan. Pilihan alasan pada setiap butir soal disusun sesuai berdasarkan pilihan jawaban. Oleh karena itu, pola distribusi pilihan jawaban seharusnya konsisten dengan pola distribusi pilihan alasan.

Berdasarkan data pada Tabel 3 pada subkonsep konfigurasi elektron stabil dan subkonsep elektron valensi, persentase kesulitan yang dialami siswa hampir sama, karena dalam menentukan konfigurasi elektron stabil dan elektron valensi suatu senyawa banyak siswa yang dapat menjawab dengan pilihan jawaban-alasan benar. Persentase kesulitan siswa pada subkonsep tiga, empat dan lima yaitu menentukan jenis ikatan ion, menentukan jenis ikatan kovalen dan menjelaskan ikatan logam kesulitan siswa mengalami peningkatan, hal disebabkan kurangnya pemahaman siswa dalam menentukan jenis ikatan ion, ikatan kovalen dan ikatan logam khususnya kecenderungan suatu unsur untuk mencapai kestabilannya dengan cara membentuk ikatan. Deskripsi kesulitan dilakukan pada persentase kesulitan paling dominan pada setiap subkonsep. 
Kesulitan siswa paling dominan dalam menyelesaikan tes kemampuan ikatan kimia terdapat pada subkonsep keempat yakni subkonsep ikatan kovalen. Kesulitan siswa dalam menentukan ikatan kovalen suatu senyawa ditelusuri dengan menggunakan instrumen TKIK yang terdiri dari tiga butir soal yakni pada butir soal nomor 10, 11, dan 12 . Berdasarkan hasil tes yang telah dilakukan diperoleh rerata jumlah siswa yang mengalami kesulitan pada subkonsep ikatan kovalen sebesar 58,6\%, dengan persentase kesulitan pada butir soal nomor 10 sebesar 57,9\%, butir soal nomor 11 sebesar 58,5\%, dan butir soal 12 sebesar 59,4\%, sehingga butir soal nomor 12 dengan kesulitan dominan pada subkonsep ikatan kovalen dideskripsikan untuk mengungkap kesulitan siswa dalam menyelesaikan TKIK dengan kategori jawaban salah-alasan salah, jawaban benar-alasan salah, jawaban salah-alasan benar, dan tidak menjawab.

Cuplikan wawancara 1 menunjukkan kesulitan yang dialami siswa dalam menentukan jenis ikatan kovalen suatu senyawa. Jawaban salah yang dipilih siswa karena sepasang elektron yang digunakan berikatan hanya berasal dari salah satu atomnya, berdasarkan hal tersebut siswa beranggapan bahwa ikatan yang ditunjukkan soal bukan merupakan ikatan kovalen koordinasi melainkan ikatan kovalen rangkap dua. Miskonsepsi dan tidak paham konsep yang dialami siswa terhadap subkonsep ikatan kovalen menyebabkan siswa mengalami kesulitan dalam menentukan jenis ikatan kovalen suatu senyawa.

Secara garis besar kesulitan siswa pada subkonsep satu yakni menentukan konfigurasi elektron stabil adalah siswa beranggapan bahwa suatu unsur dikatakan stabil karena telah memenuhi kaedah Duplet yakni memiliki dua elektron pada kulit terluarnya. Pada subkonsep dua kesulitan siswa dalam menentukan elektron valensi berdasarkan konfigurasi elektron adalah siswa beranggapan bahwa jumlah elektron valensi ditentukan berdasarkan jumlah elektron pada subkulit terakhir. Sementara itu, pada subkonsep tiga kesulitan siswa dalam menentukan jenis ikatan ion adalah siswa beranggapan bahwa ikatan ion merupakan ikatan yang terjadi karena adanya pemakaian elektron secara bersamaan dan ikatan kovalen terjadi karena adanya serah terima elektron. Kemudian, pada subkonsep empat kesulitan siswa dalam menentukan ikatan kovalen, khusunya ikatan kovalen koordinasi adalah siswa beranggapan bahwa sepasang elektron yang digunakan untuk berikatan merupakan ikatan kovalen rangkap dua 
yang digunakan secara bersama-sama. Pada subkonsep terakhir kesulitan siswa dalam menjelaskan ikatan logam adalah siswa beranggapan bahwa ikatan logam terbentuk antara unsur logam dengan nonlogam, dan terjadi karena adanya serah terima elektron antara unsur logam dengan nonlogam.

Kesulitan belajar yang dialami siswa bisa disebabkan oleh adanya beberapa faktor. Pérez, et al. (2017) mengemukakan bahwa faktor krusial yang dapat meyebabkan siswa mengalami kesulitan dalam memahami konsep adalah pengetahuan awal siswa yang tidak memadahi. Untuk dapat memahami materi ikatan kimia, materi prasyarat yang harus dikuasai siswa adalah materi atom. Siswa harus memahami tentang simbol, nomor atom, dan kecenderungan suatu unsur. Bregqvist (2017) menambahkan bahwa ketertarikan siswa untuk mempelajari suatu materi juga menjadi faktor utama yang dapat mempengaruhi ptingkat pemahaman siswa. Apabila siswa tidak termotivasi untuk mempelajari materi ikatan kimia, maka akan sulit baginya untuk dapat memahami materi yang diajarkan.

\section{SIMPULAN}

Berdasarkan penelitian yang telah dilakukan dapat disimpulkan bahwa siswa kelas X MIA SMA Negeri di Kota Palangka Raya mengalami kesulitan dalam memahami konsep ikatan kimia. Persentase kesulitan siswa dari subkonsep pertama hingga kelima yaitu: 1) konfigurasi elektron stabil $35,8 \%$; 2) elektron valensi $35,1 \%$; 3) ikatan ion $55,4 \%$; 4) ikatan kovalen 58,7\%; dan 5) ikatan logam 54,3\%.

\section{REFERENSI}

Arifin, M., 2007, Materi Pokok Pengembangan Kurikulum dan Pembelajaran Kimia, Universitas Terbuka, Jakarta.

Arikunto, S., 2007, Dasar-Dasar Evaluasi Pendidikan, Bumi Aksara, Jakarta.

Bergqvist, A., 2017, Teaching and Learning of Chemical Bonding Models: Aspects of Textbooks, Students' Understanding and Teachers' Professional Knowledge, Disertasi, Karlstad University, Swedia. Dipublikasikan.

Destama, R., 2016, Kesulitan Memahami Konsep Ikatan Kimia pada Siswa Kelas XI IPA SMA di Buntok Tahun Ajaran 2014/2015 (Studi Kasus), Skripsi, Universitas Palangka Raya, Palangka Raya. Tidak Dipublikasikan.

Herdiyansyah, F. (2017). Analisis Kesulitan Belajar Siswa Menggunakan Three-Tier Multiple Choice Diagnostic Instrument pada Materi Ikatan 
Kimia, Skripsi, Universitas Islam Negeri Syarif Hidayatullah, Jakarta. Tidak Dipublikasikan.

Mutlu,A. \& Sesen, B.A., 2015, Development of a two-tier diagnostic test to assess undergraduates' understanding of some chemistry concepts, Procedia-Social and Behavioral Sciences, 174 (2015): 629-635.

Pérez, J.R.B, Pérez, M.E., Calatayud, M.L., Garcia-Lopera, R., Montesinos, S., \& Gil, E.T., 2017, Student's Misconceptions on Chemical Bonding: A Comparative Study between High School and First Year University Students, Asian Journal of Education and e-Learning, 5(1): 2321-2454.

Sidauruk, S., 2005, Miskonsepsi Stoikiometri pada Siswa SMA, Disertasi, Universitas Negeri Yogyakarta, Yogyakarta. Tidak Dipublikasikan

Sukmadinata, N.S., 2008, Metode Penelitian Pendidikan, PT. Remaja Rosdakarya, Bandung.

Qomariah, D., 2016, Kesulitan Siswa Kelas XI IPA SMA Palangka Raya Tahun Pelajaran 2015/2016 dalam Memahami Konsep-Konsep Dasar Ikatan Kimia, Skripsi, Universitas Palangka Raya, Palangka Raya. Tidak Dipublikasikan.

Widiatmoko, A. \& Shimizu, K., 2018, The Development of Two-Tier Multiple Choice Test to Assess Students' Conceptual Understanding about Light and Optical Instruments, Jurnal Pendidikan IPA Indonesia, 7(4): 491-501. 